\title{
PENGARUH PEMBELAJARAN AKTIVITAS FISIK TERHADAP KEMAMPUAN LOMPATAN SMASH DALAM PERMAINAN BOLA VOLI SISWA KELAS VII SMP NEGERI 2 ELLA HILIR
}

\author{
Rahman $^{1}$, Nur Moh Kusuma Atmaja ${ }^{2}$, Kurnia Dyah Anggorowati ${ }^{3}$ \\ ${ }^{1}$ Mahasiswa Lulusan Program Studi PENJASKESREK Tahun 2019 \\ ${ }^{1,2}$ Dosen STKIP Melawi \\ rahmanrahmanmlw@gmail.com, atmajanur27@gmail.com, kurniadyah12@yahoo.com
}

\begin{abstract}
ABSRAK.Effect of Physical Activity Learning Ability Against Leap Smash In Game Ball voli Seventh Grade Students of SMP N egeri 2 Ella Hilir. College of Teacher Training and Education (STKIP) Melawi Study Program (Prodi) Health Physical Education and Recreation (PENJASKESREK), Supervisor 1. Nur Moh Kusuma Atmaja, M.Or, Supervisor 2, Kurnia Dyah Anggorowati, M.Or.The goal in this research was to determine the influence of the learning activities of the physical on the ability to jump an smashes in a game offootball volleyball class VII SMP Negeri 2 Ella Hilir.The research used was quasiexperimental. The research design used in this study using "One Group Pretest-Posttest Design", namely the research design that contained pretest before being treated and posttest after being treated, thus can be known more accurately. This study will compare the results of the pretest and posttest. Effectof learning Skipping Againstability Leap Smash Seventh Grade Students of SMPN 2 Ella Hilir.The results showed that there was a significant influence on the ability of volleyball smash jumps at SMP Negeri 2 Ella Hilir. This is evidenced by the statistical test results obtained by the t-test value between the pretest and posttest which has a value of t count 53.045, $t$ table $34.202(d f=21)$ at a significance level of $5 \%$, because t arithmetic is greater than t-table then there is an influence significant.
\end{abstract}

\section{Keywords: Physical Activity, Smash Leap, Volley Ball}

ABSTRAK. Pengaruh Pembelajaran Aktivitas Fisik Terhadap Kemampuan Lompatan Smash Dalam Permainan Bola voli Siswa Kelas VII SMP Negeri 2 Ella Hilir. Sekolah Tinggi Keguruan dan Ilmu Pendidikan (STKIP) Melawi, Program Studi (Prodi) Pendidikan Jasmani Kesehatan dan Rekreasi (PENJASKESREK), Pembimbing 1. Nur Moh Kusuma Atmaja, M.Or, Pembimbing 2, Kurnia Dyah Anggorowati, M.Or.Tujuan dalam peneliti ini adalah untuk mengetahui pengaruh pembelajaran aktivitas fisik terhadap kemampuan lompatan smash dalam permainan bola volisiswa kelas VII SMP Negeri 2 Ella Hilir.Penelitian yang digunakan adalah eksperimen semu. Desain penelitian yang digunakan pada penelitian ini dengan menggunakan "One Group Pretest-Posttest Design", yaitu desain penelitian yang terdapat pretestsebelum diberi perlakuan dan posttestsetelah diberi perlakuan, dengan demikian dapat diketahui lebih akurat. Penelitian ini akan membandingkan hasil pretestdan posttest. Pengaruh pembelajaran Skipping Terhadap Kemampuan Lompatan Smash Siswa Kelas VII SMPN 2 Ella Hilir.Berdasarkan analisis hasil penelitian dan pembahasan, dapat disimpulkan bahwa ada pengaruh yang signifikan pada kemampuan lompatan smash bola voli di SMP Negeri 2 Ella Hilir.Hasil penelitian dibuktikan dengan Hasil uji statistik variabel diperoleh nilai uji-t antara pretest dan posttest yang memiliki nilai t hitung 53.045, t tabel $34.202(\mathrm{df}=21)$ pada taraf signifikansi 5\%, karena t-hitung lebih besar dari t-tabel maka ada pengaruh yang signifikan.

Kata Kunci: Aktivitas Fisik, Lompatan Smash, Bola Voli 
$\mathrm{P}$ endidikan merupakan faktor yang sangat penting dalam kehidupan manusia, karena dengan adanya pendidikan di harapkan manusia dapat mengembangkan pengetahuan, keterampilan dan kreativitasnya. Keberhasilan di bidang pendidikan sangat ditentukan dalam proses pembelajaran. Proses pembelajaran merupakan rangkaian kegiatan komunikasi antara manusia yaitu antara orang yang belajar di sebut peserta didik dan orang yang mengajar di sebut guru. Dalam proses pengajaran guru akan menghadapi siswa yang mempunyai karakteristik dan kemampuan berbeda-beda sehingga guru dalam proses pembelajaran tidak akan lepas dengan masalah hasil belajar, karena hasil belajar merupakan ukuran dari kemampuan siswa dalam menerima pembelajaran di sekolah.

Didalam dunia pendidikan banyak sekali mata pelajaran yang membuat wawasan yang luas dan diantaranya pendidikan jasmani olahraga dan kesehatan merupakan pelajaran yang paling banyak di gemari oleh siswa. Pendidikan jasmani olahraga dan kesehatan memiliki peran yang sangat penting dalam mengidentifikasikan penyelenggaraan pendidikan sebagai suatu proses pembinaan manusia yang berlangsung seumur hidup. Pendidikan jasmani olahraga dan kesehatan memberikan kesempatan pada manusia untuk melihat langsung dalam aneka pengalaman belajar melalui aktivitas jasmani, bermain dan berolahraga, yang dilakukan secara sistematis, terarah dan terencana. Pembekalan pengalaman belajar itu diarahkan untuk membina, sekaligus membentukgaya hidup sehat dan aktif sepanjang hayat. Dalam pembelajaran pendidikan jasmmani olahraga dan kesehatan banyak sekali materi yang di ajarkan, salah satunya adalah permainan bolavoli.

Permainan bolavoli merupakan salah satu cabang olahraga permainan beregu yang disukai dan digemari setiap orang. permainan bola voli termasuk olahraga yang menarik, menyenangkan dan tidak membutuhkan biaya yang besar sehingga bisa dilakukan dengan mudah. Cukup membutuhkan beberapa teman, bola, net dan lahan kosong yang bisa dijadikan lapangan maka permainan bola voli bisa dilakukan. Inilah yang menjadi salah satu penyebab semakin populer dan semakin digemarinya permainan bolavoli di kalangan masyarakat di seluruh Indonesia.

Permainan bolavoli memiliki beberapa bentuk teknik dasar yang 
perlu dikuasai oleh seorang pemain. Menurut (Nuril Ahmadi 2007: 20) "dalam permainan bolavoli ada beberapa teknik dasar yang harus dikuasai, teknik dasar dalam permainan bolavoli terdiri atas servis, passing bawah, passing atas, block, dan smash". Penguasaan teknik dasar sangat penting agar bisa bermain bolavoli dengan baik. Dalam menguasai teknik-teknik dasar tersebut diperlukan latihan-latihan teknik dasar secara terus menerus dan sunggung-sungguh supaya dapat menguasai teknik bolavoli itu dengan mudah. Selain itu, semakin marak pula dengan adanya pembinaan olahraga bola voli seperti di instansi-instansi perusahaan, pemerintah dan juga di lembaga-lembaga pendidikan baik di Sekolah Dasar (SD), Sekolah Menengah Pertama (SMP), Sekolah Menengah Atas (SMA) maupun di Perguruan Tinggi.

Berdasarkan hasil observasi pada tanggal 27 Maret 2019 peneliti menemukan beberapa permasalahan atau kendala pada siswa kelas VII SMPN 2 Ella Hilir, yang dimaksud oleh peneliti yaitu pada saat proses pembelajaran berlangsung pada pelajaran pendidikan jasmani olahraga dan kesehatan dalam permainan bola volipeneliti melihat beberapa siswa yang masih kurang penguasaan gerak dasar dalam permainan bolavoli dan juga siswa masih kesulitan dalam melakukan gerak dasar lompatan smash dalam permaianan bola voli. Peneliti juga menemukan beberapa kendala pada siswa terutama kurangnya pembelajaran dalam meningkatkan lompatan pada permaian bola voli, maka perlu adanya perubahan dalam pembelajaran secara mendalam tentang gerak dasar dalam permainan bola voli.

Adapun cara untuk mengetahui hasil pembelajaran yang baik dan efektif maka penelitiakan menggunakan metode pembelajaran aktivitas fisik. Aktivitas fisik adalah setiap gerakan tubuh yang dihasilkan oleh otot rangka yang memerlukan pengeluaran energi. Aktivitas fisik yang akan diterapkan yaitu skipping. Skipping adalah suatu aktivitas yang menggunakan tali dengan kedua ujung tali dipegang dengan kedua tanganlaludiayunkan melewati kepala sampai kaki sambil melompatinya. Kelebihan dari latihan skipping adalah bisa dilakukan sendiri, bisa dilakukan dimana-mana dan tidak menggunakan biaya yang besar. Metode pembelajaran ini yang tujuanya adalah untuk meningkatkan hasil tinggi lompatan yang maksimal. Lingkup yang dipelajari dalam pembelajaran ini 
adalah power otot tungkai, sehingga dengan pembelajaran tersebut diharapkan akan memberikan peningkatan hasil tinggi lompatan. Diharapkan dengan memiliki lompatan yang tinggi dan di dukung teknik yang baik maka seorang pemain bolavoli dapat melakukansmash dengan baik.

Berdasarkan uraian di atas maka peneliti tertarik untuk mengangkat judul dalam penelitian tentang "Pengaruh Pembelajaran Aktivitas Fisik Terhadap Kemampuan Lompatan Smash Dalam Permainan BolaVoli Siswa Kelas VII SMPN 2 Ella Hilir”.

\section{METODE PENELITIAN}

\section{Jenis Penelitian}

Desain Penelitian yang digunakan adalah penelitian eksperimen. Menurut (Purwanto, 2007: 180). Penelitian eksperimen adalah penelitian dimana variabel hendak di teliti (variabel terkait) kehadirannya sengaja ditimbulkan dengan memanipulasi menggunakan. penelitian eksperimen diartikansebagai metode yang digunakan untuk mencari pengaruh perlakuan tertentu yang lain dalam kondisi yang terkendalikan.

Penelitian yang digunakan adalah eksperimen semu. Desain penelitian yang digunakan pada penelitian ini dengan menggunakan “One Group Pretest-Posttest Design”, yaitu desain penelitian yang terdapat pretest sebelum diberi perlakuan dan posttest setelah diberi perlakuan, dengan demikian dapat diketahui lebih akurat. Penelitian ini akan membandingkan hasil pretest dan posttest. Pengaruh pembelajaran Skipping Terhadap Kemampuan Lompatan Smash Siswa Kelas VII SMPN 2 Ella Hilir.

\section{$\mathrm{O}_{1} \mathrm{X} \mathrm{O}_{2}$}

\section{Gambar 3.1Pre-test dan Post-test}

(Sugiyono, 2010)

Keterangan:

$\mathbf{0}_{1}$ : Pre-test (hasil observasi sebelum pelakuan eksperimen)

$\mathbf{X}$ : Treatmen (perlakuan)

$\mathbf{0}_{2}$ : Postt-test (hasil observasi sesudah pelakuan eksperimen)

\section{Tempat dan Waktu Pelaksanaan Penelitian}

1. Tempat penelitian

Tempat penelitian akan dilakukan dikelas VII SMPN 2 Ella Hillir, alasan pemilihan tempat penelitian ini didasarkan pada letaknya tidak jauh dari peneliti 
bertempat tinggal, sedangkan pemilihan kelas VIIsebagai tempat peneliti melakukan penelitian berdasarkan adanya masalah yang dikemukakan.

2. Waktu pelaksanaan penelitian Pelaksanaan penelitian dilakukan pada tangal 24 Agustus - 21 September2019.

\section{Populasi dan Sampel Penelitian}

1. Populasi

Menurut Sugiyono (2011: 80) populasi adalah wilayah generalisasi yang terdiri atas objek atau subjek yang mempunyai kuantitas dan karakteristik tertentu yang ditetapkan oleh peneliti untuk dipelajari dan kemudian disimpulkan. Populasi dalam penelitian ini adalah siswa SMPN 2 Ella Hilir kelas VII berjumlah 22 orang.

2. Sampel penelitian

Sampel adalah bagian yang mewakili populasi yang diambil dengan menggunakan teknik-teknik tertentu. Teknik sampel yang digunakan dalam penelitian yaitu observasi. Pengumpulan data saat penelitian menggunakan lembar tes dan pengukuran berupa berlari dan melompat.
Tabel 3.1. Sampel Penelitian

\begin{tabular}{|c|l|c|}
\hline $\begin{array}{c}\text { Model } \\
\text { pembelajaran }\end{array}$ & $\begin{array}{c}\text { Jumlah } \\
\text { siswa }\end{array}$ & Keterangan \\
\hline $\begin{array}{c}\text { Aktivitas } \\
\text { fisik }\end{array}$ & 22 & $\begin{array}{c}\text { Kelas } \\
\text { Eksperimen }\end{array}$ \\
\hline
\end{tabular}

Sumber: TU SMPN 2 Ella Hilir

Teknik Pengumpulan Data dan Instrumen Penelitian

1. Teknik Pengumpulan Data

Arikunto, (2010: 100) mengatakan "teknik pengumpulan data adalah cara-cara yang dapat dipergunakan oleh peneliti untuk mengumpulkan data". Dalam penelitian ini teknik pengumpulan data yang digunakan untuk mengukur hasil belajar adalah: Teknik Tes, Teknik pengumpulan data dalam penelitian ini menggunakan tes hasil belajar yang mengukur aspek psikomotor (gerak) tentang pelaksanaan proses pembelajaran yang dilakukan oleh peneliti.

2. Instrumen Penelitian

Menurut Arikunto, Sebagaimana dikutip oleh Trianto (2009:271) bahwa ada keterkaitan antara metode dan instrument penilaian, di mana instrument penilaian merupakan alat bantau bagi gurudalam menggunakan metode evaluasi 
penilaian proses dan produk pembelajaran pemilihan satu jenis kadang-kadang dapat memerlukan lebihdari satu jenis instrument. Sebaliknya, satu jenis instrument dapat digunakan untuk berbagai macam metode.

Instrumen pengumpulan data yang digunakan peneliti dalam penelitian ini yaitu Observasi. Tes dan pengukuran yang digunakan penelitiuntuk mengetahui gerak dasar lompat melalui permainan bola voli di Sekolah Menengah Pertama, disini peneliti menggunakan tes berupalompatan, tes yang di berikan kepada siswa berupa indikator gerak dasar lompat.

\section{Variabel Penelitian}

Menutut Suharsimi Arikunto (2006:118) "Variabel adalah objek yang penelitian atau apayang menjadi

titik perhatian suatu penelitian". Adapun variable penelitian ini adalah sebagai berikut:

1. Variabel bebas (X)

Variabel bebas atau variabel independen ( $\mathrm{x}$ ) yaitu merupakan variabel yang mempengaruhi atau yang menjadi sebab perubahanya atau timbulnya variabel dependen (terikat), variabel bebas dalam penelitian ini adalah melalui permainan bola voli

2. Variabel terikat (Y)

$$
\text { Variabel terikat adalah }
$$

variabel yang nilainya yang bergantung pada variabel lainya dilambangkan dengan (Y). variabel terikat dalam penelitian adalah aktvitas fisik dalam lompatan smash.

\section{Validitas dan Reliabilitas Instrumen}

1. Validitas

"Validitas berasal dari kata validity yang berarti sejauhmana ketepatan dan kecermatan pengukur (tes) dalam melakukan fungsi ukurnya (Azwar, 2011:122).

Instrumen yang valid berarti memiliki validitas tinggi, demikian pula sebaliknya. Suatu instrumen dikatakan valid apabila mampu mengukur apa yang diinginkan atau mengungkapkan data dari variabel yang diteliti secara tepat. Validitas yang dipergunakan untuk mengukur soal hasil belajar yaitu validitas empiris, yang bertujuan untuk menentukan tingkat kehandalan soal. Penentuan tingkat validitas butir soal digunakan korelasi Product Moment Pearson dengan mengkorelasikan antara skor yang didapat siswa pada 
butir soal dengan skor total yang didapat.Dipergunakan rumus sebagai berikut:

$$
\begin{aligned}
& \mathrm{r}_{\mathrm{xy}}= \\
& \frac{N \sum x y-\left(\sum x\right)\left(\sum \mathrm{y}\right)}{\sqrt{\left[N\left(\sum X^{2}\right)-\left(\sum x\right)^{2}\right]\left[N\left(\sum Y^{2}\right)-\left(\sum Y\right)^{2}\right]}}
\end{aligned}
$$

Keterangan:

$r_{x y}=$ Koofisien korelasi antara

variabel $\mathrm{X}$ dan $\mathrm{Y}$

$\mathrm{N}=$ Banyaknya peserta tes

$\mathrm{X}=$ Skor siswa pada butir $\mathrm{k}-1$

$\mathrm{Y}=$ Skor total siswa

Interprestasi terhadap nilai koofisien korelasi $\mathrm{r}_{\mathrm{xy}}$ digunakan kriteria Nurgana (dalam Jakni, 2016: 165), yaitu sebagai berikut:

$0,80<r_{x y} \leq 1,00=$ sangat tinggi

$0,60<r_{x y} \leq 0,80=$ tinggi

$0,40<\mathrm{r}_{\mathrm{xy}} \leq 0,60=$ cukup

$0,20<\mathrm{r}_{\mathrm{xy}} \leq 0,40=$ rendah (soal bisa diperbaiki atau diganti)

$r_{x y} \leq 0,20=$ sangat rendah (soal bisa diperbaiki atau diganti)

Berdasarkan perhitungan dengan menggunakan rumus korelasi Product moment diperoleh hasil sebagai berikut :
Tabel 3.8. Hasil Analisis

Validitas

\begin{tabular}{|c|c|c|l|}
\hline $\begin{array}{c}\text { No Gerak } \\
\text { Dasar } \\
\text { Lompatan }\end{array}$ & rxy & Ket & Kriteria \\
\hline 1 & 0,93 & Valid & Sangat Tinggi \\
\hline 2 & 0,98 & Valid & Sangat Tinggi \\
\hline 3 & 0,91 & Valid & Sangat Tinggi \\
\hline 4 & 0,92 & Valid & Sangat Tinggi \\
\hline 5 & 0,94 & Valid & Sangat Tinggi \\
\hline 6 & 0,97 & Valid & Sangat Tinggi \\
\hline 7 & 0,95 & Valid & Sangat Tinggi \\
\hline 8 & 0,96 & Valid & Sangat Tinggi \\
\hline 9 & 0,98 & Valid & Sangat Tinggi \\
\hline
\end{tabular}

Data hasil validitas di atas menunjukan bahwa soal Pretest yang digunakan dinyatak valid dan layak digunakan dalam penelitian.

2. Reliabilitas Instrumen

"Reliabilitas adalah tingkat atau derajat konsistensi dari suatu instrumen”, Arifin (2015: 258). Suatu tes dapat dikatakan valid maka reliabel jika selalu memberikan hasil yang sama bila diteskan pada kelompok yang sama pada waktu atau kesempatan yang berbeda. Instrumen tes hasil belajar ini dianggap reliabel karena bersifat umum, sehingga jika di pergunakan atau diberikan kepada siswa dengan kelas yang sama, maka hasilnya sama, yang membedakan hanya tingkat kemampuan 
siswa. "Untuk mengetahui reliabilitas instrumen hasil.

\section{HASIL PENELITIAN}

Penelitian ini merupakan penelitian eksperimen one group pretest posttest yang menggunakan satu kelas sebagai kelas eksperimen pada pendidikan jasmani. Pada penelitian ini menggunakan metode aktivitas fisik terhadap kemampuanlompatan Smash dalam permainan bola voli Siswa Kelas VII SMPN 2 Ella Hilir.

Penelitian dilakukan pada tanggal 23 Agustus - 21September2019 selama 4 kali pertemuan setiap hari Sabtu, mulai pukul 07.00-09.00 WIB. Subyek dalam penelitian ini adalah siswa SMP Negeri 2 Ella Hilir yang berjumlah 22 orang siswa yang terdiri dari 11 siswi perempuan dan 11 orang siswa laki-laki.

Sebelum materi pembelajaran disampaikan tahap awal yang diberikan kepada siswa sebelum mendapatkan perlakuanpretestyang dilakukan pada tanggal 23 Agustus 2019. Tujuannya adalah untuk mengetahui keadaan awal setiap siswa dan posttest diberikan setelah semua materi disampaikan oleh peneliti, dengan tujuan untuk mengetahui keadaan akhir setiap siswa seteleh diberikan perlakuan treatmentyang dilakukan pada tanggal 21 September 2019.

Untuk analisis data digunakan Uji- $t$, yaitu dengan membandingkan hasil nilai dari pretest dan posttest. Sebelum dilakukan uji hipotesis terlebih dahulu dilakukan uji prasyarat dengan uji normalitas dan uji homogenitas data. Proses analisis data hasil penelitian ini menggunakan bantuan program komputer SPSS versi 21.0.

\section{Data Deskripsi SMP Negeri 2 Ella} Hilir

Deskripsi data penelitian berfungsi untuk mempermudah penelitian yang telah dilakukan. Deskripsi data penelitian meliputi data pretest dan posttest SMP Negeri 2 Ella Hilir.

Tabel 4.1. Data Tes SMP Negeri 2 Ella Hilir

\begin{tabular}{|c|c|c|c|}
\hline No & Kode Siswa & Pretest & Posttest \\
\hline 1 & DFVD & 77,78 & 88,89 \\
\hline 2 & DND & 66,67 & 88,89 \\
\hline 3 & DS & 55,55 & 77,78 \\
\hline 4 & DSD & 55,55 & 88,89 \\
\hline 5 & EDE & 77,78 & 88,89 \\
\hline 6 & FRKY & 66,67 & 77,78 \\
\hline 7 & IRN & 77,78 & 88,89 \\
\hline 8 & LS & 66,67 & 88,89 \\
\hline
\end{tabular}




\begin{tabular}{|c|c|c|c|}
\hline 9 & LNS & 55,55 & 77,78 \\
\hline 10 & LH & 77,78 & 88,89 \\
\hline 11 & MR & 55,55 & 77,78 \\
\hline 12 & MRH & 77,78 & 88,89 \\
\hline 13 & Nova & 66,67 & 88,89 \\
\hline 14 & OSS & 55,55 & 66,67 \\
\hline 15 & PRA & 77,78 & 88,89 \\
\hline 16 & FKA & 66,67 & 88,89 \\
\hline 17 & SBN & 77,78 & 88,89 \\
\hline 18 & SNR & 55,55 & 66,67 \\
\hline 19 & SPRDI & 66,67 & 77,78 \\
\hline 20 & VKR & 77,78 & 88,89 \\
\hline 21 & YD & 66,67 & 88,89 \\
\hline 22 & ZC & 77,70 & 88,89 \\
\hline Jumlah Total & $\mathbf{1 . 5 0 0 , 0 1}$ & $\mathbf{1 . 8 5 5 , 6 0}$ \\
\hline Nilai rata-rata & $\mathbf{6 8 , 1 8}$ & $\mathbf{8 4 , 3 4}$ \\
\hline
\end{tabular}

Tabel 4.1. Menunjukkan bahwa nilai Pretest (test awal) pada pertemuan pertama dengan jumlah total keseluruhan sebesar 1.500,01 dengan nilai rata-rata Pretestnya adalah sebesar 68,18 sedangkan total nilai Posttest nyaadalah 1.855,60 dengan nilai rata-rata keseluruhannya sebesar 84,34. Dapat disimpulkan bahwa dari hasil tes Pretest dan Posttest menunjukkan adanya peningkatan yaitu sebesar 16,16\%. Berdasarkan KKM dalam penelitian ini tentun sudah memenuhi kriteria keberhasilan.

Tabel 4.2. Stastistik Hasil Penelitian

\begin{tabular}{|l|r|r|}
\hline & Pretest & \multicolumn{1}{|c|}{ Posttest } \\
\hline $\mathrm{N}$ & 22 & 22 \\
ValidMissing & 1 & 1 \\
Mean & 4.874 & 8.633 \\
Median & 0.529 & 2.707 \\
Mode & 9 & $10^{\mathrm{a}}$ \\
Std. Deviation & 740.06 & 926.07 \\
Minimum & 55.55 & 66.67 \\
Maximum & 77.78 & 88.89 \\
Sum & 7.118 & 10.497 \\
\hline
\end{tabular}

Multiple modes exist. The smallest value is shown

Berdasarkan tabel 4.2. pretest ketrampilan gerak dasar lompatan smash SMP Negeri 2 Ella Hilir memiliki nilai minimum 55,55 nilai maksimum 77,78 rerata 68.18, median 0.529 dan standar deviasi 740.06. Sedangkan posttest memiliki nilai minimum 66.67 nilai maksimum 88.89 rerata 84.34 , median 2.707, dan standar deviasi 926.07

\section{Pengujian Normalitas}

Tujuan dari uji normalitas adalah untuk mengetahui apakah data yang diperoleh dari hasil tes 
sebenarnya mengikuti pola sebaran normal atau tidak. Uji normalitas variabel dilakukan dengan menggunakan Kolmogorov-Smirnov dan pengerjaannya menggunakan program komputer SPSS 21.0. Kaidah yang digunakan untuk mengetahui normal tidaknya suatu sebaran adalah apabila nilai signifikan lebih besar dari 0,05 (signifikan > 0,05), maka normal dan apabila nilai signifikan kurang dari 0,05 (signifikan <0,05) dikatakan tidak normal (Jonathan Sarwono, 2010: 25). Uji normalitas dapat dilihat pada tabel berikut:

Tabel 4.3. Hasil Uji Normalitas Data

\begin{tabular}{|l|l|c|l|}
\hline No & \multicolumn{1}{|c|}{ Variable } & Sig. & Ket. \\
\hline 1 & Pretest & 0.011 & Normal \\
\hline 2 & Posttest & 0.016 & Normal \\
\hline
\end{tabular}

Berdasarkan tabel 4.3. Dari sisi lain dapat dilihat pada nilai signifikannya, yaitu 0,011 untuk pretest dan 0.016 untuk posttest. Karena nilai kedua signifikan semuanya lebih besar dari 0,05 (signifikan > 0,05) maka hipotesis yang menyatakan bahwa data berdistribusi normal.

\section{Uji Homogenitas}

Uji homogenitas dilakukan untuk mengetahui kesamaan variansi atau untuk menguji bahwa data yang diperoleh berasal dari populasi yang homogen. Kriteria pengambilan keputusan diterima apabila nilai signifikan lebih besar dari 0,05 (signifikan > 0,05) (Jonathan Sarwono, 2010: 86). Hasil uji homogenitas adalah sebagai berikut:

Tabel 4.4. Hasil Uji Homogenitas

\begin{tabular}{|l|c|c|l|}
\hline Kelompok & $\begin{array}{c}\text { Levence } \\
\text { Statistik }\end{array}$ & Sig & Keterangan \\
\cline { 1 - 3 } Pretest & 17.755 & $\begin{array}{c}0.11 \\
1\end{array}$ & Homogen \\
\cline { 1 - 2 } Posttest & & 1 \\
\hline
\end{tabular}

Berdasarkan tabel 4.4. Hasil uji homogenitas variabel penelitian diketahui nilai levence statistik sebesar 17.755 sedangkan nilai signifikansi lebih besar dari 0,05 yaitu sebesar 0.111. Karena signifikan lebih besar dari 0,05 maka hipotesis yang menyatakan bahwa data diperoleh dari sampel yang homogen, diterima.

\section{Pengujian Hipotesis}

$$
\text { Pengujian }
$$

hipotesis

dilakukan untuk mengetahui ada atau tidaknya pengaruh pembelajaran aktivitas fisik terhadap kemampuan 
lompatan Smash dalam permainan bola voli siswa kelas VIISMP Negeri 2 Ella Hilir. Di uji dengan mencari perbedaan ketrampilan tes nilai atau skor terbanyak. Uji hipotesis menggunakan uji-t yang hasilnya dapat dilihat pada tabel berikut:

Tabel 4.5. Hasil Uji $-t$

\begin{tabular}{|l|l|l|l|c|}
\hline Variable & Rata-rata & hitung & T table & Ket \\
\hline Pretest & 68.18 & 53.045 & 34.202 & $\begin{array}{c}\text { Signifi } \\
\text { kan }\end{array}$ \\
\hline Posttest & 84.34 & & & \\
\hline
\end{tabular}

Berdasarkan tabel 4.5. Hasil uji statistik variabel diperoleh nilai uji-t antara pretest dan posttest yang memiliki nilai t_hitung 53.045, t_tabel $34.202(\mathrm{df}=21)$ padataraf signifikansi 5\%, karena t_hitung lebih besar dari t_tabel maka ada pengaruh yang signifikan. Jika dilihat dari besarnya pengaruh pembelajaran aktivitas fisik terhadap kemampuan lompatan Smash Dalam permainan bola voli siswa kelas VII SMPNegeri 2 Ella Hiliradalah sebagai berikut:

\section{Tabel 4.6. Pengaruh pembelajaran} aktivitas fisik terhadap kemampuanlompatan Smash

\begin{tabular}{|c|c|c|}
\hline Kelompok & Rerata & $\begin{array}{c}\text { Kenaikan } \\
\text { Persentase }\end{array}$ \\
\hline Pretest & 68.18 & $16.16 \%$ \\
\hline Posttest & 84.34 & \\
\hline
\end{tabular}

Berdasarkan tabel 4.6. Dilihat dari nilai rata-rata, maka diperoleh nilai rata-rata pretest adalah 68,18 dan nilai rata-rata posttest 84,34 , dengan rerata adalah 69,32. Dari rerata tersebut dapat diketahui kenaikan persentase dengan cara rerata dibagi rerata posttest dikalikan 100\%, sebesar 82\%. Hal ini mempunyai arti bahwa ada pengaruh pembelajaran aktivitas fisik terhadap kemampuan lompatan Smash dalam permainan bola voli siswa kelas VII SMPNegeri 2 Ella Hiliryaitu sebesar $82 \%$.

\section{Pembahasan}

Penelitian ini bertujuan untuk mengetahui pengaruh pembelajaran aktivitas fisik terhadap kemampuan lompatan Smash dalam permainan bola voli siswa kelas VII SMPNegeri 2 Ella Hilir. Hasil penelitian menunjukkan bahwa ada pengaruh yang signifikan pada kemampuan lompatan smash peserta didik di SMPN 2 Ella Hilir. Untuk dapat bermain voli dengan baik seorang pemain harus dibekali dengan skill atau kemampuangerak dasar yang baik. Sehingga kemampuan gerak dasar bermain voli sangat dibutuhkan sekali dalam permainan atau pertandingan bola voli. 
Hal ini dibuktikan dengan menggunakan kaidah untuk mengetahui ada atau tidak adanya pengaruh signifikan, yaitu apabila nilai t hitung lebih besar dari t-tabel, maka Ha diterima dan jika nilai signifikan $\mathrm{t}$ hitung kurang dari t-tabel, maka $\mathrm{Ha}$ ditolak. Berdasarkan hasil uji statistik variabel maka Ha diterima. karena nilai t hitung (53.045) lebih besar dari t tabel (34.202) maka ada pengaruh yang signifikan. Dilihat dari nilai rata-rata, maka diperoleh nilai rata-rata pretest adalah 68,18 dan nilai rata-rata posttest 84,34 dengan selisih rerata adalah 69,32. Dari selisih rerata tersebut dapat diketahui kenaikan persentase dengan cara selisih rerata dibagi rerata posttest dikalikan $100 \%$, sebesar $82 \%$. Hal ini mempunyai arti bahwa ada perbandingan ketrampilan bola voli yaitu sebesar $82 \%$. Pengemasan rencanapembelajran yang disesuaikan dengan kemampuan dan tingkat kesulitan gerak dasar yang diajarkan, mampu memberikan perubahan yang signifikan pada peningkatan kemampuan lompatan smash bola voli. pembelajaran aktivitas fisik terhadap kemampuan lompatan smash dalam permainan bola voli Siswa Kelas VII SMP Negeri 2 Ella Hilir

\section{DAFTAR PUSTAKA}

Ahmadi, Nuril. 2007. Panduan Olahraga Bola Voli. Solo: Era pustaka Utama, jakarta

Arikunto, Suharsimi. 2010. Prosedur

Penelitian Suatu Pendekatan

Praktik. Jakarta: Rhineka Cipta

Arifin. 2015. Penelitian Pendidikan Metode dan Pradigma Baru. Bandung: Remaja Rosda Karya Azwar. 2011. Reliabilitas dan Validitas.Yogyakarta: Pustaka Pelajar

Purwanto. 2007. Metodologi Penelitian

Kuantitatif. Yogyakarta: Pustaka Pelajar

Sugiyono. 2011. Metode Penelitan Pendekatan

PendidikanKuantitatif,

Kualitatif dan $R \& D$. Bandung:

Alfabeta

\section{KESIMPULAN}

Berdasarkan hasil penelitian dan pembahasan dapat di simpulkan bahwa adanya pengaruh yang signifikan 